\title{
EXTERNAL AND SENSORY QUALITIES OF BROWN LAYING HEN EGGS FED DIETS SUPPLEMENTED WITH PURSLANE (Portulaca oleracea) MEAL RICH IN OMEGA-3 FATTY ACIDS
}

\author{
Lilik Retna Kartikasari*, Bayu Setya Hertanto and Adi Magna Patriadi Nuhriawangsa \\ Department of Animal Science, Faculty of Agriculture, Universitas Sebelas Maret, Jl. Ir. Sutami 36A, Surakarta \\ 57126, Indonesia \\ *Corresponding author: lilikretna@staff.uns.ac.id
}

Accepted 15 March 2019; Revised 18 September 2019

Published 17 October 2019

\begin{abstract}
This study was conducted to evaluate the external physical quality and sensory quality of eggs fed diets added with purslane meal (Portulaca oleraceae) as a source of alpha-linolenic acids. The materials used were Hy-Line Brown laying hen ( $n=150$ hens, 54 weeks old). The design of the study was a one way classification with five experimental diets. Each diet was replicated five times with five hens for each replication. The diets were formulated by supplementing purslane meal to a basal diet. The levels of purslane meal were $0 \%$ (T0), $2 \%$ (T1), 4\% (T2), 6\% (T3), 8\% (T4). The diets were given to the hens for 35 days with 7 days of adaptation period. To analyse the external quality of the eggs, a total of 30 eggs ( $n=6$ per dietary treatment) collected at day 33, 34, and 35 were used. The sensory analysis used eggs from day 32. The results of the external quality of eggs showed that the addition of purslane meal (Portulaca oleracea) into the diets of laying hens reaching a level of $8 \%$ tended to increase egg weight and did not decrease shell thickness, shell weight, the shape index, and specific gravity $(\mathrm{P}>0.05)$. Dietary inclusion of purslane meal up to a level of $8 \%$ significantly increased $(\mathrm{P}<0.01)$ the preference of egg yolk color while texture, taste, flavor, and overall acceptance were not affected. The conclusion is that purslane meal can be included in the laying hen diets up to a level of $8 \%$ without decreasing the external physical quality and the sensory quality of boiled eggs. Diets containing purslane meal increase the preference of egg yolk color due to the increase in yolk color intensity.
\end{abstract}

Keywords: External physical quality; sensory quality; laying hens; purslane meal. 


\section{INTRODUCTION}

Eggs are animal food products that have the potential to meet human nutrition requirements because eggs contain high nutritional value. The nutritional content of egg yolk is protein $17.07 \%$, fat $32.21 \%$, and minerals 2.03\% (Faitorone et al., 2013). Efforts to improve the quality of eggs can be pursued through feeding strategies. Diets supplemented with feed ingredients rich in omega-3 (n-3) fatty acids, sourced from the sea, such as fish meal and fish oil has been reported to increase the n-3 fatty acid content of eggs produced, especially in the form of eicosapentaenoic acid and docosahexaenoic acid (Cachaldora et al., 2008 and Lawlor et al., 2010). A study conducted by Garcia-Rebollar et al. (2008) found that the addition of fish meal or fish oil to the feed had a negative effect on the quality of egg sensory, mainly related to consumer acceptance. Eggs containing n-3 fatty acids (EPA and DHA) tend to have fishy and off-flavor aromas (Bou et al., 2005 and Chekani-Azar et al., 2008). Therefore, an alternative source of alpha-linolenic acid (n-3 PUFA / ALA) is needed from plants. ALA is a precursor of all n-3 long chain fatty acids (n-3 LCPUFA) that are very beneficial for human health, especially eicosapentaenoic acid (EPA) and docosahexaenoic acid (DHA).

Purslane (Portuca oleraceae) is a plant rich in PUFA n-3 fatty acids that is commonly found in Indonesia (Aydin and Dogan, 2010). About $100 \mathrm{~g}$ of fresh purslane leaves contain $400 \mathrm{mg}$ ALA (Uddin et al., 2014). Purslane is also rich in calcium, potassium, $\beta$-carotene, folic acid, vitamin $C$, and anti-oxidants (Irawan et al., 2003).
Fresh purslane contains calcium $65 \mathrm{mg} /$ $100 \mathrm{~g}$, potassium $494 \mathrm{mg} / 100 \mathrm{~g}$, magnesium $68 \mathrm{mg} / 100 \mathrm{~g}$, alpha-tocopherol $22.2 \mathrm{mg} /$ $100 \mathrm{~g}$; ascorbic acid $26.6 \mathrm{mg} / 100 \mathrm{~g}$ (Uddin et al., 2014), and beta-carotene $5.4 \mathrm{mg} /$ $100 \mathrm{~g}$ (Irawan et al., 2003).

The use of plant sources rich in n-3 PUFA is expected to be able to enrich the content of n-3 fatty acids and egg quality without decreasing the organoleptic quality of eggs. The increase of ALA content in chicken feed also has the potential to provide health benefits for chickens. Kartikasari et al. (2017) reported that the total n-3 PUFA of chicken heart tissue increased by 4-5-fold with an increase in the level of n-3 PUFA feed. One of the determinants of the external quality of eggs, among others, is the strength of the shell so that adequate calcium availability can affect the process of eggshell formation (Jacob et al., 2009). The research results of Kartikasari (2013) showed that the use of ALA from plant sources such as canola and flaxseed in the form of vegetable oil can increase the content of n-3 LCPUFA without reducing egg production and quality. According to the research of Nobakht (2014), the use of $2 \%$ purslane has no effect on the quality of eggshell compared to control. Kartikasari et al. (2015) found that supplementation of purslane meal to a level of $6 \%$ increased egg yolk colour, and did not reduce the quality of eggs such as egg weight, egg yolk weight, albumin index, yolk index and haugh unit value. Leeson and Summer (2005) found that increasing ALA in feed can increase egg size and weight. In relation to the organoleptic quality of the product, Irawan et al. (2003) added that there was no
*Corresponding author:

Lilik Retna Kartikasari

Email: lilikretna@staff.uns.ac.id

Department of Animal Science, Faculty of Agriculture, Universitas Sebelas Maret, Jl. Ir. Sutami 36A, Surakarta 57126, Indonesia
How to cite:

Kartikasari, L. R., Hertanto, B. S., \& Nuhriawangsa, A. M. P. (2019). External and Sensory Qualities of Brown Laying Hen Eggs Fed Diets Supplemented with Purslane (Portulaca oleracea) Meal Rich in Omega-3 Fatty Acids. Jurnal Ilmu dan Teknologi Hasil Ternak, 14 (2), 78-89 
negative effect on egg sensory quality with the addition of n-3 fatty acids sourced from vegetable. In terms of quantity and quality, purslane plants have the potential as an alternative feed source of alpha-linolenic acid which can replace n-3 fatty acids from the sea. until now, there is little information and data related to the quality of egg produced with the use of purslane meal, especially in brown laying hens, has not been done much. Based on the description above, it is necessary to study the physical and organoleptic quality of chicken eggs from laying hens fed dietary treatments enriched with purslane meal.

\section{MATERIALS AND METHODS}

\section{Research material}

The study used 150 laying hens of HyLine brown strains aged 54 weeks, with an average body weight of $1.84 \pm 0.11 \mathrm{~kg}$. Other research materials used were the ingredients of a basal diet and purslane meal. Other nutrients needed for laying hens were prepared according to the National Research Council/NRC (1994).

\section{Research methods}

The research design was a Complete Random Design in a unidirectional pattern. The treatment factor was five dietary treatments and each treatment consisted of six replications. Each replication used five laying hens. Upon arrival, laying hens were immediately given sugar and water, and then were weighed to obtain the initial body weight. All chickens were then placed in individual cages that had been given a code that indicated the treatment and replication. The location of the cage is determined randomly through the draw. The dietary treatment consisted of a basal diet based on corn and soybeans with purslane meal supplementation. The composition of the experimental diets were basal diet $+0 \%$ purslane meal (T0), basal diet $+2 \%$ purslane meal (T1), basal diet $+4 \%$ purslane meal (T2), basal diet $+6 \%$ purslane meal (T3), and basal diet $+8 \%$ purslane meal (T4). The purslane used in this study was a red purslane. The method of producing purslane meal follows the procedure described by (Evaris et al., 2015) with several modifications, with the following steps: 1) purslane was cleaned first, then the roots were removed and cut into pieces; 2) purslane was aerated; 3) purslane was heated in an oven at a temperature of 55$60^{\circ} \mathrm{C}$ for $72 \mathrm{~h}$; and 4) purslane was mashed in a flour mill machine and then sieved with a mesh sieve (size 80) to obtain purslane meal. The purslane meal contains $18.5 \%$ of total n-3 fatty acids, consisting of $18 \%$ of PUFA (ALA) $18 \%$ and EPA of $0.5 \%$ (Waite Lipid Analysis Service, School of Agriculture, Food and Wine, University of Adelaide, Australia). The composition of the dietary treatments and nutritional value of the diets are shown in Table 1. The chickens were kept for 35 days with an adaptation period of 7 days. Feed provided for adaptation consisted of $100 \%$ basal diet (day 1), mixture of basal diet and experimental diet with a ratio of 75:25 (day 2, 3), 50:50 (day 4), 25:75 (day 5, 6) and 0:100 (day 7). Dietery treatments and drinking water were provided in an ad libitum manner. The time of feeding was at 06:30 am and $14.00 \mathrm{pm}$. Egg collection for external quality testing was carried out on the $35^{\text {th }}$ day. Eggs were collected at 11:00 am and 16:30 pm. The number of eggs tested was 1 egg for each replication per day and was taken randomly. External quality data was then analyzed statistically. The evaluation of boiled egg sensory quality used eggs produced on the $32^{\text {nd }}$ day of rearing chickens.

\section{Egg weight testing}

Eggs were placed on the egg tray, then weighed using a digital scale with an accuracy of $0.01 \mathrm{~g}$. The individual weight of the egg was then calculated (Dunn-Horrocks et al., 2011).

\section{Egg index testing}

The egg index was determined by measuring and comparing the width of the egg to the length of the egg. To determine 
the egg index, the following formula (Gul et al., 2012) was used:

Egg index $(100)=\frac{\text { Egg width }}{\text { Egg lenth }} \times 100$

\section{Egg specific gravity testing}

The egg specific gravity $(\mathrm{g} / \mathrm{ml})$ was measured by the Archimedes method with a tool designed to determine the egg volume. Density can be calculated by the formula (Hamilton, 1982) as follows:
Egg density $(\mathrm{g} / \mathrm{ml})=\frac{\text { Egg weight }(\mathrm{g})}{\text { Egg volume }(\mathrm{ml})}$

\section{Shell weight testing}

The weight of the shell was measured by separating the shell from the egg yolk and the albumen after breaking the egg. Egg shells were washed with running water then the shells were heated in the oven at $60^{\circ} \mathrm{C}$ for $12 \mathrm{~h}$. Eggshells were weighed using a digital scale with accuracy of $0.01 \mathrm{~g}$ (Cufadar, 2014).

Table 1. The proportion of feed ingredients and nutrient content in the diets

\begin{tabular}{|c|c|c|c|c|c|}
\hline \multirow{2}{*}{ Feed ingredients } & \multicolumn{5}{|c|}{ Purslane Flour Addition Level (\%) } \\
\hline & T0 & $\mathrm{T} 1$ & $\mathrm{~T} 2$ & $\mathrm{~T} 3$ & $\mathrm{~T} 4$ \\
\hline Yellow Corn & 53.00 & 53.00 & 53.00 & 53.00 & 53.00 \\
\hline Soybean meal & 24.90 & 24.50 & 23.71 & 23.30 & 23.00 \\
\hline Rice bran & 7.53 & 6.57 & 6.15 & 4.85 & 2.20 \\
\hline DCP & 1.30 & 1.34 & 1.34 & 1.34 & 1.34 \\
\hline Lime flour & 2.15 & 1.90 & 1.70 & 1.46 & 1.21 \\
\hline$D L$-metionin & 0.15 & 0.15 & 0.15 & 0.15 & 0.15 \\
\hline$L$-lysin & 0.10 & 0.10 & 0.10 & 0.10 & 0.10 \\
\hline Premix & 0.30 & 0.30 & 0.30 & 0.30 & 0.30 \\
\hline Limestone & 4.90 & 4.90 & 4.88 & 4.88 & 4.88 \\
\hline Salt & 0.15 & 0.15 & 0.15 & 0.15 & 0.15 \\
\hline Palm oil & 3.00 & 3.07 & 3.00 & 3.20 & 4.65 \\
\hline Coconut cake & 1.00 & 1.00 & 1.00 & 1.00 & 1.00 \\
\hline purslane meal & 0.00 & 2.00 & 4.00 & 6.00 & 8.00 \\
\hline Vitamin E & 0.02 & 0.02 & 0.02 & 0.02 & 0.02 \\
\hline Filler & 1.50 & 1.00 & 0.50 & 0.25 & 0.00 \\
\hline Total & 100.00 & 100.00 & 100.00 & 100.00 & 100.00 \\
\hline \multicolumn{6}{|l|}{ Nutrient Content } \\
\hline EM (kkal/kg) & 2925.40 & 2925.09 & 2919.68 & 2922.87 & 2852.17 \\
\hline Crude protein $(\%)$ & 17.04 & 17.11 & 17.06 & 17.13 & 17.02 \\
\hline Crude fat $(\%)$ & 3.37 & 3.36 & 3.42 & 3.37 & 3.13 \\
\hline Crude fiber (\%) & 3.34 & 3.66 & 4.00 & 4.33 & 4.48 \\
\hline $\operatorname{Ash}(\%)$ & 2.99 & 2.93 & 2.90 & 2.83 & 2.64 \\
\hline Phosphor (\%) & 0.65 & 0.65 & 0.65 & 0.63 & 0.60 \\
\hline Available phosphor (\%) & 0.37 & 0.37 & 0.37 & 0.37 & 0.35 \\
\hline Calcium (\%) & 3.10 & 3.10 & 3.10 & 3.10 & 3.10 \\
\hline Methionine (\%) & 0.43 & 0.42 & 0.42 & 0.41 & 0.40 \\
\hline Lysine (\%) & 0.96 & 0.94 & 0.92 & 0.90 & 0.88 \\
\hline
\end{tabular}

\section{Sensory quality testing}

The panelists used were semi-trained panelists. Panelists were recruited by asking questions using a questionnaire, especially about the possibility of an allergy to eggs, the level of preference and frequent 
consumption of eggs. A total of 33 panelists who met the criteria provided an assessment of the organoleptic quality of eggs. Sample preparation and sensory evaluation procedure were performed according to Kartikasari (2013). Chicken eggs were washed clean then boiled in boiling water for $8 \mathrm{~min}$, then cooled with running water. The eggshells were peeled slowly from boiled eggs then the boiled eggs were cut into 4 parts and placed inside a closed container coded with a random 3-digit number for organoleptic testing. After testing one sample, panelists were asked to drink water and eat original crackers to neutralize the taste. For consumer acceptance testing, panelists were given a questionnaire containing a 9-point hedonic scale (Lawlor et al., 2010) and filled out the form by putting a check mark $(\sqrt{ })$ on the points according to the panelists' preference level for the sample. The choices of the 9 point hedonic scale were (1) dislike extremely, (2) dislike very much, (3) dislike moderately, (4) dislike slightly, (5) neither like nor dislike, (6) like slightly, (7) like moderately, (8) like very much and like extremely (9).

\section{Data analysis}

Research data were tested using analysis of variance to determine whether there was any effect of dietary treatment on the variables tested (Minitab 17, Minitab Inc. 2015). If there was a treatment effect, testing was continued with the Duncan's Multiple Range Test to find out the differences among the means (Gul et al., 2012).

\section{RESULTS AND DISCUSSION}

\section{External quality of eggs}

Analysis of variance revealed that there were no significant effects of different diets on egg weight, egg index, egg specific gravity, eggshell weight and eggshell thickness (Table 2).

Table 2. External quality of eggs with the addition of purslane meal in the diets

\begin{tabular}{|c|c|c|c|c|c|c|}
\hline \multirow{2}{*}{ Variable } & \multicolumn{5}{|c|}{ Treatment } & \multirow{2}{*}{$\begin{array}{l}\text { Significance } \\
\text { level }\end{array}$} \\
\hline & T0 & T1 & $\mathrm{T} 2$ & T3 & T4 & \\
\hline Egg weight (g) & 56.81 & 62.45 & 64.58 & 64.96 & 64.78 & NS \\
\hline Egg index & 0.65 & 0.67 & 0.71 & 0.65 & 0.65 & NS \\
\hline $\begin{array}{l}\text { Egg specific gravity } \\
(\mathrm{g} / \mathrm{ml})\end{array}$ & 1.09 & 1.09 & 1.09 & 1.09 & 1.08 & NS \\
\hline Eggshell weight (g) & 5.68 & 5.72 & 6.31 & 6.02 & 5.76 & NS \\
\hline $\begin{array}{l}\text { Eggshell thickness } \\
(\mathrm{mm})\end{array}$ & 0.34 & 0.32 & 0.35 & 0.33 & 0.34 & NS \\
\hline
\end{tabular}

T0, basal diet; T1, basal diet $+2 \%$ purslane meal; $\mathrm{T} 2$, basal diet $+4 \%$ purslane meal; T3, basal diet $+6 \%$ purslane meal and $\mathrm{T} 4$, basal diet $+8 \%$ purslane meal; NS $=$ not significant .

\section{Egg weight}

Supplementation of purslane meal (Portulaca oleracea) to the level of $8 \%$ in the diets of brown laying hens did not have a significant difference in egg weight although there was a tendency for an increase in egg weight $(\mathrm{P}<0.1)$. The results obtained were supported by the results of research by Gheisari and Ghayor (2014) which found that there were no differences in egg weight produced from chickens fed with rapeseed oil supplementation up to the level of $20 \%$. In addition, a study conducted by Kartikasari et al. (2015) showed that the feeding of ALA rich diet to the $6 \%$ level did not affect the egg weight.

The egg weight in this study was not significantly different because it was likely caused by the weight of the albumen which did not increase. Chicken eggs consist of $64 \%$ of the albumen so the weight of the albumen affects the weight of the eggs produced (Amrullah, 2003). Protein is the main constituent of albumen. The relatively 
equal protein content in the experimental diets (Table 1) resulted in no increase in albumen weight. The results obtained are supported by the analysis of albumen weights which did not increase with the addition of purslane meal (Kartikasari et al., 2017).

The tendency to increase egg weight by purslane meal supplementation in the diet is likely due to the increase in egg yolk weight with the addition of purslane meal in laying hen diet. Kul and Seker (2004) stated that egg weight is directly proportional to egg yolk weight. The increase in egg yolk weight is probably due to the fact that ALA in purslane meal is deposited on egg yolk. The results obtained were supported by the results of egg yolk weight analysis which showed an increase in egg yolk weight by the addition of purslane meal (Kartikasari et al., 2017). The average of chicken egg weight fed with the addition of purslane meal was $62.71 \mathrm{~g}$. Egg weights in this study were classified as normal and included in the large classification. According to SNI (2008), egg weights for consumption are classified into $<50 \mathrm{~g}$ (small), 50-60 g (medium) and > $60 \mathrm{~g}$ (large). This result is also supported by the opinion of Rasyaf (2004) which stated that the normal egg weight of purebred chicken was $57.6 \mathrm{~g}$ per egg.

\section{Egg index}

The results showed that the egg index was not significantly different $(\mathrm{P}>0.05)$ with the dietary inclusion of purslane meal (Portulaca oleracea) to the level of $8 \%$ (Table 2). The data obtained was supported by research carried out by Melviyanti et al. (2013) who found that the use of functional feed containing n-3 fatty acids in chickens did not significantly differ in the value of the egg index.

These results were probably caused by the calcium content in the feed which was relatively similar so that the shape of the eggs produced would be the same. According to Yuwanta (2004), the variation in egg length and width was influenced by the nutrient content of laying hens, especially calcium because it plays an important role in the process of calcification of eggshells. The correlation between the length and width of the eggshell can determine the value of the egg index (Fadilah and Fatkhuroji, 2013). The results of the current study showed that the egg had an elongated oval shape because the egg index value was between $0.65-0.71$. This value is still below the normal egg index standard.

This is based on the statement of Gul et al. (2012) who reported that the egg index value is in the range between 0.73-0.75. The egg index obtained in this study is likely due to the age factor of chickens that have entered the post production phase that is above 54 weeks. This is in line with the opinion of Yuwanta (2010) who said that the egg index will decrease progressively with increasing age.

\section{Egg specific gravity}

The results of the study showed that supplementation of purslane meal up to a level of $8 \%$ did not result in a significant difference $(\mathrm{P}>0.05)$ on egg specific gravity (Table 2). The data obtained is in accordance with the opinion of Najib and Al-Yousef (2010) that the use of essential fatty acids to the level of $20 \%$ had no significant effect on egg specific gravity. The specific gravity achieved was probably due to the relatively similar calcium and phosphorus content of the dietary treatment (Table 1), so the calcium content in the eggshell was also no different. According to Nascimento et al. (2014), egg specific gravity was influenced significantly by calcium consumption. This statement is supported by the opinion of Harmayanda et al. (2016) which stated that calcium consumption has a positive effect on egg specific gravity. The egg specific gravity obtained in this study was 1,085 1,097 and this result is quite good and normal. This is based on the opinion of Ahmad et al. (2003) which stated that good egg quality had a specific gravity above 1.070 . 


\section{Eggshell weight}

The eggshell weight of laying hens fed with the addition of purslane meal to the level of $8 \%$ had no significant effect (P> 0.05; Table 2). The mean weight of shells obtained in this study was 5.68; 5.72; $6.31 ; 6.02$ and 5.76 at the additional levels of purslane meal 0, 2, 4, 6 and $8 \%$, respectively. The results are in accordance with those reported by Bean and Leeson (2003) that the addition of 10\% ALA-rich flaxseed in the diet did not affect the weight of the shells both in brown and white laying hens.

This result is supported by the opinion of Yassein et al. (2015) which said that the use of flaxseed up to the $15 \%$ level had no effect on eggshell weight. The quality of shells is closely related to the supply of calcium obtained during the process of eggshell formation (Suprijatna et al., 2008; Jacob et al., 2009). Purslane plants contain calcium which reaches $65 \mathrm{mg} / 100 \mathrm{~g}$ (Uddin et al., 2014). The absence of eggshell weight differences is likely due to the relatively similar calcium content in the diet between dietary treatments, which is around $3.10 \%$. The percentage of eggshell weight is between $9-10 \%$ of egg weight. Sokolowics et al. (2018) stated that the weight of eggshells is around $10-12 \%$ of the total egg weight. The results showed that the quality of eggshells produced by supplementing purslane meal in feed resulted in optimal quality of shells.

\section{Eggshell thickness}

Supplementation of purslane meal (Portulaca oleracea) to the level of $8 \%$ did not show any significant effect $(\mathrm{P}>0.05)$ on eggshell thickness as shown in Table 2. The mean of eggshell thickness in this study was $0.34 ; 0.32 ; 0.35 ; 0.33$ and 0.34 with the addition of $0,2,4,6$ and $8 \%$ purslane meal, respectively. The results were supported by Nobakht (2014) that the addition of purslane by $2 \%$ in the Hi-Line chicken diet (W-36 strain) did not significantly affect the thickness of the shells. Bean and Leeson (2003) also reported that adding 10\% flaxseed to the diet did not change the thickness of the eggshell produced by both brown and white laying hens.

The lack of difference in eggshell thickness between the control and experimental diets might also be caused by the relatively similar balance of calcium and phosphorus in the diet from each dietary treatment, as shown in Table 1. The availability of phosphorus and calcium in the diet could influence the thickness of the shell (Leeson and Summers, 2005; Ahmad et al., 2003). This suggests that the quality of eggshells is determined by the thickness and structure of the skin. Therefore, it is important to consider the calcium content in the diet so that laying hens can produce an optimal eggshell. A study conducted by Sokolowics et al. (2018) found that the thickness of eggshell ranges from 0.30 to $0.35 \mathrm{~mm}$. The average thickness of the eggshell from this study is $0.34 \mathrm{~mm}$, thus the eggshell is good quality.

\section{Consumer preference assessment}

Sensory attributes of egg yolk assessed by consumers included color, texture, taste, aroma, taste and overall preferences, as shown in Table 3.

\section{Egg yolk colour}

Analysis of variance showed that purslane meal supplementation to the level of $8 \%$ has a very significant effect $(\mathrm{P}<0.01)$ on egg yolk preference. Color is one of the main parameters related to consumer desires for eggs. Increased egg yolk color might be related to the presence of natural pigments in purslane. Kartikasari et al. (2017) reported that increasing levels of dietary purslane meal increased yolk color intensity. This is because purslane is a plant that contains many nutrients such as $\beta$-catotene and xanthophylls (Raju et al., 2007; Uddin et al., 2014). The increase in egg yolk colour intensity fed with supplementation of purslane meal is likely due to the purslane meal consumed by chickens as a source of $\beta$-catotene and yolk xanthophylls (Raju et al., 2007). Increasing the level of purslane 
meal increases the amount of xanthophylls and vitamin A in egg yolk, thereby increasing the intensity of the color of the yolk.

Table 3. Consumer preferences of boiled eggs produced from hens fed experimental diets added with purslane meal

\begin{tabular}{llccccc}
\hline \multirow{2}{*}{ Variable } & \multicolumn{5}{c}{ Treatment } & Significance \\
\cline { 2 - 6 } & T0 & T1 & T2 & T3 & T4 & level \\
\hline Colour & $5.27^{\mathrm{b}}$ & $5.60^{\mathrm{ab}}$ & $5.66^{\mathrm{ab}}$ & $6.33^{\mathrm{a}}$ & $6.51^{\mathrm{a}}$ & $* *$ \\
Texture & 5.90 & 5.90 & 5.81 & 6.03 & 5.66 & $\mathrm{NS}$ \\
Aroma & 5.69 & 5.90 & 5.69 & 5.90 & 5.69 & $\mathrm{NS}$ \\
Taste & 5.72 & 6.09 & 6.15 & 6.03 & 6.30 & $\mathrm{NS}$ \\
Flavor & 6.03 & 6.00 & 5.93 & 6.03 & 5.97 & $\mathrm{NS}$ \\
Overall acceptance & 6.03 & 6.21 & 6.21 & 6.30 & 6.09 & NS \\
\hline
\end{tabular}

T0, basal diet; $\mathrm{T} 1$, basal diet $+2 \%$ purslane meal; $\mathrm{T} 2$, basal diet $+4 \%$ purslane meal; $\mathrm{T} 3$, basal diet $+6 \%$ purslane meal and $\mathrm{T} 4$, basal diet $+8 \%$ purslane meal; NS $=$ not significant.

\section{Egg texture}

The results showed that supplementation of purslane meal to the level of $8 \%$ had no effect on the rating score on egg texture preference, One factor that is likely to play a role in egg yolk texture is the yolk fat content, and this result is in line with the study of Kartikasari et al. (unpublished data) that the purslane meal supplementation in laying hen diet did not show differences in egg yolk fat content. An increase in n-3 fatty acid content of the diets might increase the n-3 fatty acid content of eggs produced, but had no effect on egg fat content, so it had no effect on the texture of egg yolks. This result is supported by research of Hayat et al. (2010) who found that the addition of flaxseed rich in n-3 fatty acids in laying hens had no effect on egg texture.

\section{Aroma}

Panelists' assessment of egg flavor preference did not differ by the addition of purslane meal to diets up to the level of $8 \%$. According to Setyaningsih et al. (2010), the aroma evaluation shows sensory properties that require sensitivity in feeling and smelling food. Based on the hedonic test of boiled eggs, it was shown that the consumer's preference for aroma was 'like slightly' (score 5.8). The results obtained are as reported by Tserveni-Gousi et al. (2001) that the supplementation of flaxseed and tymus meal resulted in normal aroma preferences. Hayat et al. (2010) added that the use of flaxseed to laying hen diets did not affect the sensory quality of eggs and consumer preferences, especially the aroma of eggs.

\section{Taste}

The results of consumer preference analysis showed that purslane meal supplementation did not influence the taste of eggs. Panelist rating of the taste of boiled eggs is 'like slightly'. This is because purslane plants have high antioxidant content (Irawan et al., 2003). According to Fraeye et al. (2012) antioxidant substances can maintain the stability of egg fat so it does not affect the taste of eggs. This result is as reported by Hayat et al. (2010) that the addition of flaxseed to the diets of laying hens provided consumers with normal taste preferences.

\section{Flavor}

The results of the study found that purslane meal supplementation up to a level of $8 \%$ did not influence the egg flavor. These results are in line with Irawan et al. (2003) who reported that supplementation of n-3 fatty acids sourced from vegetable did not have a negative effect on egg sensory quality. In addition, a study conducted by Hayat et al. (2010) found that panelists could not detect differences in flavor between boiled eggs produced from diets added with 
$10 \%$ flaxseed and from the control diet. The results obtained indicate that lipid oxidation does not contribute to the emergence of offflavors or 'fishy' flavor in eggs resulting from feeding supplemented with n-3 fatty acids sourced from plants, for example extruded flaxeed up to a level of 10\% (Imran et al., 2015). The average score of consumer preferences for flavor was 6.2, which was 'like slightly'. The results obtained are supported by the panelist perception for aroma and taste which also did not differ between control eggs and eggs produced from chicken fed diets with the addition of purslane meal. Winarno (2002) adds that the assessment of aroma and taste plays an important role in the producing of flavor, which determines the level of consumer preferences.

\section{Overall acceptance}

There was no difference in the panelists' assessment of the overall acceptance of eggs produced by laying hens fed diets supplemented with purslane meal to the level of $8 \%$. The average score of consumer preference for overall acceptance of eggs is 'like slightly'. This is because overall, the eggs produced are similar to regular eggs. Although the color of the yolk is higher in intensity, it does not affect overall consumer preferencesThis is in accordance with a study carried out by Hayat et al. (2010) which reported that the addition of flaxseed and vitamin $\mathrm{E}$ as antioxidants did not have a significant effect on overall consumer acceptance. TserveniGousi et al. (2001) added that the addition of flaxseed and thymus meal had no effect on aroma, taste and overall acceptance. Sensory quality in overall is influenced by the assessment of taste and aroma (Winarno, 2002)

\section{CONCLUSION}

It can be concluded that purslane meal (Portulaca oleraceae) can be used in laying hens with a maximum level of $8 \%$ without decreasing the external quality and sensory quality of the eggs. Diet containing purslane meal increases consumer preference for egg yolk color because of intensed egg yolk color.

\section{ACKNOWLEDGMENT}

The authors thank Universitas Sebelas Maret for providing research funding through PNBP PK-UNS 2016.

\section{REFERENCE}

Ahmad, H. A., Yadalam, S. S., \& Roland, D. (2003). Calcium requirements of bovanes hends. International Journal of Poultry Science, 2, 417-420.

Amrullah, I. K. (2003). Nutrisi Ayam Petelur. Bogor: Satu Gunung Budi.

Aydin, R., \& Dogan, I. (2010). Fatty acid profile and cholesterol content of egg yolk from chickens fed diets supplemented with purslane (Portulaca oleracea L.). Journal of the Science of Food and Agriculture, 90(10), 1759-1763. https://doi.org/ $10.1002 /$ jsfa. 4018

Bean, L., \& Leeson, S. (2003). Long-term effects of feeding flaxseed on performance and egg fatty acid composition of brown and white hens. Poultry Science, 82(3), 388-394. https://doi.org/10.1093/ps/82.3.388

Betti, M., Schneider, B. L., Wismer, W. V, Carney, V. L., Zuidhof, M. J., \& Renema, R. A. (2009). Omega-3enriched broiler meat: 2. functional properties, oxidative stability, and consumer acceptance. Poultry Science, 88(5), 1085-1095. https:// doi.org/10.3382/ps.2008-00158

Bou, R., Guardiola, F., Barroeta, A. C., \& Codony, R. (2005). Effect of dietary fat sources and zinc and selenium supplements on the composition and 
consumer acceptability of chicken meat. Poultry Science, 84(7), 11291140. https://doi.org/10.1093/ps/84.7.1129

Cachaldora, P., García-Rebollar, P., Alvarez, C., Blas, J. C. DE, \& Méndez, J. (2006). Effect of type and level of fish oil supplementation on yolk fat composition and n-3 fatty acids retention efficiency in laying hens. British Poultry Science, 47(1), 43-49. https://doi.org/10.1080/00071 660500475541

Cufadar, Y. (2012). Effect of alternative calcium sources on performance and eggshell quality in laying hens. Journal of Macro Trends in Applied Science, 2(1), 10-15.

Dunn-Horro, S., Pichardo-F, M., Lee, J., Ruiz-Feria, C., Creger, C., Hyatt, D., Farnell, M. (2011). Effect of omega-3 enriched layer rations on egg quality. International Journal of Poultry Science, 10(1), 8-11. https://doi.org/ 10.3923/ijps.2011.8.11

Evaris, E., Sarmiento-Franco, L. A., Segura-Correa, J. C., \& CapetilloLeal, C. M. (2015). Effect of dietary inclusion of purslane (Portulaca oleracea 1.) on yolk omega-3 fatty acids content, egg quality and productive performance of rhode island red hens. Tropical and Subtropical Agroecosystems, 18, 33-38.

Fadilah, R., \& Fatkhuroji. (2013). Memaksimalkan Produksi Ayam Ras Petelur. Jakarta: Agro Media Pustaka.

Faitarone, A. B., Garcia, E., Roça, R. de. O., Ricardo, H. de. A., Andrade, E. N. de, Pelícia, K., \& Vercese, F. (2013). Cholesterol levels and nutritional composition of commercial layers eggs fed diets with different vegetable oils. Revista Brasileira de Ciência Avícola, 15(1), 31-37. https://doi.org/

\subsection{0/S1516-635X2013000100006}

Fraeye, I., Bruneel, C., Lemahieu, C., Buyse, J., Muylaert, K., \& Foubert, I. (2012). Dietary enrichment of eggs with omega-3 fatty acids: A review. Food Research International, 48(2), 961-969. https://doi.org/10.1016/J.F OODRES. 2012.03.014

García-Rebollar, P., Cachaldora, P., Alvarez, C., De Blas, C., \& Méndez, J. (2008). Effect of the combined supplementation of diets with increasing levels of fish and linseed oils on yolk fat composition and sensorial quality of eggs in laying hens. Animal Feed Science and Technology, 140(3-4), 337-348. https://doi.org/10.1016/J.ANIFEEDS CI.2007.03.006

Gul, M., Yoruk, M. A., Aksu, T., Kaya, A., \& Kaynar, O. (2012). The effect of different levels of canola oil on performance, egg shell quality and fatty acid composition of laying hens. International Journal of Poultry Science, 11(12), 769-776. https://doi. org/10.3923/ijps.2012.769.776

Hamilton, R. M. G. (1982). Methods and factors that affect the measurement of egg shell quality. The Journal of Poultry Science, 61, 2022-2039. https://doi.org/10.2141/jpsa.41.161

Imran, M., Anjum, F. M., Nadeem, M., Ahmad, N., Khan, M. K., Mushtaq, Z., \& Hussain, S. (2015). Production of Bio-omega-3 eggs through the supplementation of extruded flaxseed meal in hen diet. Lipids in Health and Disease, 14, 126. https://doi.org/ 10.1186/s12944-015-0127-x

Irawan, D., Hariyadi, P., \& Wijaya, H. (2003). The Potency of krokot (portulaca oleracea) as functional food ingredients. Indonesian Food and 
Nutrition Progress, 10(1), 1-12. https://doi.org/10.22146/jifnp.89

Jacob, J. P., Miles, R. D., \& Mather, F. B. (2009). Egg Quality. Gainesville.

Kartikasari, L. R. (2003). Omega-3 long chain polyunsaturated fatty acid (n-3 LCPUFA) levels in chicken products following consumption of alphalinolenic acid enriched diets. University of Adelaide.

Kartikasari, L. R., Hertanto, B. S., Pranoto, D., Salim, W. N., \& Nuhriawangsa, A. M. P. (2017). Materials Science and Engineering. In Paper presented at Scopus-Indexed Proceedings IOP Conference. https://doi.org/10.1088/ 1757-899X/193/1/012027.

Kartikasari, L. R., Nuhriawangsa, A. M. P., Hertanto, B. S., \& Swastike, W. (2015). Production Performance and Quality of Eggs of Laying Hens Fed Diets Supplemented with Plants Rich in alpha-Linolenic Acid. In Paper presented at the 6th International Seminar on Tropical Animal Production. Yogyakarta: Gadjah Mada University.

Lawlor, J., Gaudette, N., Dickson, T., \& House, J. (2010). Fatty acid profile and sensory characteristics of table eggs from laying hens fed diets containing microencapsulated fish oil. Animal Feed Science and Technology, 156(3-4), 97-103. https://doi.org/10. 1016/J.ANIFEEDSCI.2010.01.003

Leeson, S., \& Summer, J. D. (2005). Commercial Poultry Nutrition. (O. Guelph, Ed.) (3rd ed.). Canad: University Books.

Melviyanti, M. T., Iriyanti, N., \& Roesdiyanto. (2013). Penggunaan pakan fungsional mengandung omega-3, probiotik dan isolate
Antihistamin n3 terhadap bobot dan indeks telur ayam kampung. Jurnal Ilmiah Peternakan, 1, 677-683.

Najib, H., \& Al-Yousef, Y. A. (2010). Essential fatty acid content of eggs and performance of layer hens fed with different levels of full-fat flaxseed. Journal of Cell and Animal Biology, 4(3), 58-63.

Nascimento, G. do, Murakami, A., Guerra, A., Ospinas-Rojas, I., Ferreira, M., \& Fanhani, J. (2014). Effect of different vitamin D sources and calcium levels in the diet of layers in the second laying cycle. Revista Brasileira de Ciência Avícola, 16(2), 37-42. https://doi.org/10.1590/1516-635x160237-42

National Research Council. (1994). Nutrient Requirements of Poultry (9th ed.). Washington, D.C: Natlional Academy Press.

Nobakht, A. (2014). The Effects of different levels of portulaca oleracea, medicinal plant, on performance, egg quality, blood biochemical and immunity parameters of mature laying hens. Iranian Journal of Applied Animal Science, 4(2), 393-397.

Raju, M., Varakumar, S., Lakshminarayana, R., Krishnakantha, T. P., \& Baskaran, V. (2007). Carotenoid composition and vitamin A activity of medicinally important green leafy vegetables. Food Chemistry, 101(4), 1598-1605. https: //doi.org/10.1016/J.FOODCHEM.200 6.04 .015

Rasyaf, M. (2004). Beternak Ayam Pedaging. Jakarta: Penebar Swadaya.

Rath, P. K., Mishra, P. K., Mallick, B. K., \& Behura, N. C. (2015). Evaluation of different egg quality traits and interpretation of their mode of 
inheritance in White Leghorns. Veterinary World, 8(4), 449-452. https://doi.org/10.14202/vetworld.201 5.449-452

Rusconi, M., \& Conti, A. (2010). Theobroma cacao L., the Food of the Gods: A scientific approach beyond myths and claims. Pharmacological Research, 61(1), 5-13. https://doi. org/10.1016/j.phrs.2009.08.008

Setyaningsih, D., Apriyanto, A., \& Sari, M. (2010). Analisis Sensori untuk Industri Pangan dan Pertanian. Bogor: Institut Pertanian Bogor Press.

Sokołowicz, Z., Krawczyk, J., \& Dykiel, M. (2018). Effect of alternative housing system and hen genotype on egg quality characteristics. Emirates Journal of Food and Agriculture, 30(8), 695-703. https://doi.org/10. 9755/ejfa.2018.v30.i8.1753

Standar Nasional Indonesia. (2008). Telur Ayam Konsumsi (SNI 3926:2008). Jakarta: Badan Standardisasi Nasional.

Suprijatna, E., Atmomarsono, U., \& Kartasudjana, R. (2008). Ilmu Dasar Ternak Unggas. Jakarta: Penebar Swadaya.

Tserveni-Gousi, A. S. (2001). Sensory evaluation of eggs produced by laying hens fed diet containing flaxseed and Thymus meal. Archiv Fur Geflügelkundes, 65, 214-218.
Uddin, M. K., Juraimi, A. S., Hossain, M. S., Nahar, M. A. U., Ali, M. E., \& Rahman, M. M. (2014). Purslane weed (Portulaca oleracea): a prospective plant source of nutrition, omega-3 fatty acid, and antioxidant attributes. The Scientific World Journal, 2014, 951019. https://doi. org/10.1155/2014/951019

Yamamoto, T., Juneja, L. R., Hatta, H., \& Kim, M. (2007). Hen Eggs: Basic and Applied Science. Canada: University of Alberta.

Yassein, S. A., El-Mallah, G. M., Ahmed, S. M., El-Ghamry, A. A., AbdelFattah, M. M., \& El-Hariry, D. M. (2015). Response of laying hens to dietary flaxseed levels on performance, egg quality criteria, fatty acid composition of egg and some blood parameters. International Journal of Research Studies in Biosciences, 3(10), 27-34.

Yuwanta, T. (2004). Dasar Ternak Unggas. Yogyakarta: Penerbit Kanisius.

Yuwanta, T. (2010). Telur dan Kualitas Telur. Yogyakarta: Gadjah Mada Press. 